\title{
History of Education
}

History of Education is a half-yearly journal sponsored by the History of Education Society, which was founded in 1967 to promote the study of this subject in all its aspects. It contains original articles on the development of education both in Britain and abroad - schools and colleges, teaching methods, personalities, the politics of education and its philosophy. Some papers are illustrated with plates and drawings, and the journal is concluded with a section of book reviews. It is edited by Malcolm Seaborne, Principal of Chester College, in conjunction with an editorial board of distinguished scholars, including several corresponding members overseas.

\section{Volume 2 Number 1}

January 1973

Contents: A Didactic Introduction to Arithmetic, Sir Charles Cotterell's 'Instrument for Arithmeticke' of 1667, D J Bryden; Elementary School Attendance and Voluntary Effort Before 1870, Nancy Ball; The Reform of the Endowed Schools: The Work of the Northamptonshire Educational Society 1854-1874, David Allsobrook; Joseph Chamberlain and Free Education in the Election of 1885, Alan Simon; New Perspectives in the History of American Education 1960-1970, Sol Cohen. Book Reviews. 104 pages plus 4 pages of plates.

Volume 2 Number 2

June 1973

Contents: Church Records and the History of Education in Early Modern England 1558-1642: A Problem in Methodology, Rosemary O'Day: The Commission for National Education in Poland 1773-1794, Lucasz Kurdybacha; Educational Capital in the Elementary School of the MidNineteenth Century, Raymond Pallister; French Views of the English Public Schools: Some Nineteenth-Century Episodes, R D Anderson; Education and the Labour Movement: A Critical Review of the Literature, Harold Silver. Book Reviews. 104 pages plus 4 pages of plates.

\section{Annual subscription $\$ 6.50$ post free}

\section{Published by}

\section{DAVID \& CHARLES}

\section{NEWTON ABBOT DEVON . ENGLAND}

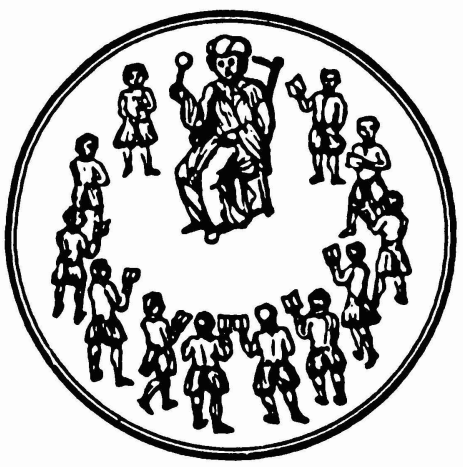




\section{SPRING 1973}

\section{IN HOC SIGNO? A Brief History of Catholic Parochial Education}

in America by Glen Gabert, Jr.

Have the Catholic schools been a success or a failure? Are they needed today? Can and should they survive? Now that the financial condition of the parochial schools has reached crisis proportions and various state aid proposals are being debated, searching questions about their role and function are being asked.

In Hoc Signo? is a study of the problems facing the Catholic schools in historical perspective. Drawing more heavily on official documents than authors of previous studies-papal writings and hierarchical statements-Glen Gabert is able to construct a revisionary interpretation of Catholic education in the U.S. that challenges the official history at many points.

\section{BLACK STUDIES: Threat or Challenge? by Nick Aaron Ford}

This monumental study by an eminent Black educator and humanist presents the first comprehensive, fully documented report on the history, scope, effects, and the future development of Black Studies programs in American schools and colleges.

"Its aim is to present, in language which a layman can understand, a professional evaluation of the past history, present practices, and future possibilities of Black Studies in the officially recognized educational programs of American colleges and universities...."-from the author's Preface

Order these original National University Publications from 
HISTORY OF EDUCATION QUARTERLY

\section{TABLE OF CONTENTS}

\section{Fall 1973}

\section{ARTICLES}

Philosophical Anthropology and Educational Change:

Wilhelm Von Humboldt and the Prussian Reforms

By Carla Thomas

Colonial Studies in Imperial Germany

By Jake Spidle

WORKS IN PROGRESS

Conformity and Rebellion: Contrasting Styles of English and German Youth, 1900-1933

By John Gillis

\section{DISCUSSION}

The Ante-Bellum College Movement: A Reappraisal of Tewkesbury's The Founding of American Colleges and Universities

By Natalie Naylor

ESSAY REVIEWS

Juvenile Delinquency in Perspective

By Robert Mennell

The Triumph of the American High School

By Joel Spring

Social History and Modern French Education

By Peter Lamour

Chinese Education as an Instrument of Change

By Jessie Lutz

Puritan Education in Seventeenth Century England and New England 
